\title{
NATIONAL AND REGIONAL ECONOMIC SECURITY: ASSESSMENT INDICES
}

\author{
Daniil Beloshitskii \\ Omsk Humanitarian Academy, Omsk, Russia \\ Oleg Patlasov \\ K.G. Razumovski Moscow State University of technologies and management, Russia \\ Omsk Humanitarian Academy, Professor, Omsk, Russia \\ It has been argued that national methods of economic security of the Russian Federation use \\ only economic indicators, while foreign practice, including the UN methodology, \\ supplements social, environmental and political indicators to the list of economic ones to be \\ used as the basis. There are no weight functions being included for the indicators analysis in \\ An attempt to determine indicators reflecting the economic security level of a country and its \\ individual regions has been made. It is demonstrated that all officially approved methods are \\ fraught with disregard for regions and small states peculiarities. The necessary indicators \\ are identified to be included into analysis and ranked as national and regional ones. Based \\ on the studies performed and the results obtained, the most repeated indicators existed in all \\ the investigated methods have been found. A universal model has been developed using \\ indicators to determine a reliable level of economic security.
} some of the analyzed methods.

Keywords: economic security, methodologies and safety indicators, country risks

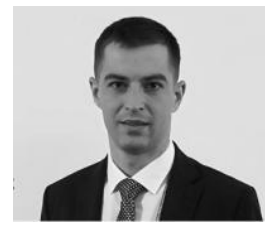

\section{Daniil Beloshitskii}

PhD-Student, Omsk Humanitarian Academy, Omsk, Russian Federation Research Interests: Economics, Economic Security, World Economy

e-mail: daniil-beloshickijj@yandex.ru

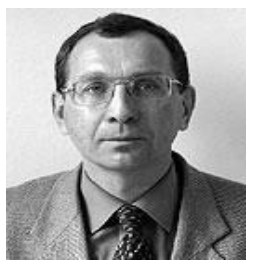

\section{Oleg Patlasov}

Doctor of economy, professor,

Chief- specialist of the Federal State Budget Educational Institution of Higher Education K.G. Razumovski Moscow State University of technologies and management; Omsk Humanitarian Academy

Research interests: Risk Management, Economic Analysis and Financial Management, Personnel Marketing

e-mail: opatlasov@mail.ru 


\section{NATIONAL AND REGIONAL ECONOMIC SECURITY}

\section{Introduction}

National political administrations are forced to pay considerable attention to economic independence despite the complexity and diversity of this problem,. The very concept of "economic security" understood in the broad sense has appeared quite recently in connection with the globalization of the world economy.

To determine the level of economic security, it is necessary to set a list of indicators used to define it. The choice of indicators used for the correct construction of economic security analysis is the most relevant topic in this area. Nowadays there is no exact insight into indicators necessary to develop a correct analysis in countries and regions, especially the regions having specific conditions (Haikel, 2004).

The problem of determining the reliability and accuracy of these economic security indicators has been raised at an international level by the United Nations, IMF, the World Bank and leading universities of the world.

In practice, there are significant limitations when one needs to choose indicators; it is so due to the variety of approaches when selecting an indicator of a different level of economic security; these include:

- supranational snapshot (European Union),

- country level (economic security of individual countries);

- regional security (in relation to the Russian Federation, federal districts, constituent entities of the federation, cities and municipalities).

It seems quite problematic to build a universal model including a certain set of indicators and meeting all the necessary requirements, since the amount of available data and the nature of application scope cause serious problems concerning the reliability of the information received and the complexity of its systematization (Kazakova et al., 2016).

Furthermore, some indicators are of specific character and are not used in a number of regions because of their uselessness. So, it is impossible to use them objectively determining the economic security of a country due to the obvious data corruption.

The purpose of the study is to determine the most reliable indicators to determine the economic security of countries and regions.

\section{Literature Review}

The methodologies related to the country level, primarily with regard to the Russian Federation have been analyzed.

The indicators introduced by various national and foreign authors and organizations have been analyzed to consider the issue comprehensively.

All methods measuring economic security can be divided into the following groups:

- International (UN);

- Regulated analysis based on the authorities approved methods (President of the Russian Federation, 2017);

- Scientific (Center for financial and banking research, Institute of Economics, RAS);

- Authorial Methodology (Glazyev \& Lokosov, 2012).

Economic security in many developed countries is an integral part of intelligence and special units concern, but in our country (as part of the USSR) only special units took care of economic security and access to it was limited until recently. 
On this basis, it can be concluded that economic security is the direction of economic intelligence dealing with protection of sovereignty, national assets, and reputation, ensuring the stable functioning and development of economic mechanisms, and also helping to strengthen the model of sustainable economic growth. If we determine the economic security level correctly, it will make it possible to take advanced measures responding to emerging threats (Denis, 2014).

The UN Security Commission proposed to present the indicators in four categories: economic, social, environmental and political ones as it is given in Table 1 (Manokhina, 2018).

Table 1 - System of economic security indicators developed

\begin{tabular}{|c|c|c|c|}
\hline Economic indicators & Social indicators & $\begin{array}{c}\text { Environmental } \\
\text { performance }\end{array}$ & $\begin{array}{l}\text { Policy Management } \\
\text { Indicators }\end{array}$ \\
\hline GDP per capita & Gini coefficient & Ecological system & $\begin{array}{l}\text { Publicity and } \\
\text { accountability }\end{array}$ \\
\hline $\begin{array}{c}\text { Industrial production, } \\
\text { growth rate }\end{array}$ & $\begin{array}{l}\text { Government expenditure } \\
\text { on education ( } \% \text { of GDP) }\end{array}$ & $\begin{array}{c}\text { Environmental stress } \\
\text { reduction }\end{array}$ & Political stability \\
\hline Fixed capital investments & $\begin{array}{l}\text { Government health } \\
\text { expenditure (\% of } \\
\text { GDP) }\end{array}$ & Vulnerability reduction & State effectiveness \\
\hline $\begin{array}{c}\text { Consumer price index, } \\
\text { growth rate }\end{array}$ & Average life expectancy & $\begin{array}{c}\text { Social and institutional } \\
\text { opportunities }\end{array}$ & $\begin{array}{c}\text { State regulation } \\
\text { effectiveness }\end{array}$ \\
\hline $\begin{array}{c}\text { Government debt } \\
(\% \text { of GDP })\end{array}$ & Employment, growth rate & Supervision & $\begin{array}{c}\text { Effectiveness of } \\
\text { laws }\end{array}$ \\
\hline $\begin{array}{c}\text { The share of exports of } \\
\text { high-tech products } \\
(\% \text { of GDP })\end{array}$ & Unemployment rate, $\%$ & & $\begin{array}{l}\text { Corruption } \\
\text { overcoming }\end{array}$ \\
\hline $\begin{array}{c}\text { Research and development } \\
\text { costs (\% of GDP) }\end{array}$ & $\begin{array}{c}\text { Number of Internet } \\
\text { resources users }\end{array}$ & & \\
\hline $\begin{array}{c}\text { Share of services } \\
(\% \text { of GDP })\end{array}$ & $\begin{array}{c}\text { The number of telephone } \\
\text { lines and cellular } \\
\text { subscribers (per } 1000 \\
\text { people) }\end{array}$ & & \\
\hline GDP deflator growth rate & & & \\
\hline
\end{tabular}

This set of indicators has a number of advantages, since it affects the most significant areas that can influence the economic situation in the country. In particular, a mixed approach is used to determine economic security. The following approach for further determination of economic security level will use several methods of finding, since political and environmental indicators can only be defined by expert assessment, while economic and social indicators can be considered using various methods. But these indicators cannot be used completely for individual regions having their own specifics; it is most relevant for the regions of Russia.

Political, managerial and environmental indicators are of rather vague significance, since satisfaction with the environment or political situation in one entity (region) does not 


\section{NATIONAL AND REGIONAL ECONOMIC SECURITY}

always express the solidarity of other entities, and the overall result may turn to be positive and may not correspond with reality.

The economic security indicators have also been developed in the Russian Federation. In 1996, a system of economic security indicators was first developed and approved on the instructions of the Security Council of the Russian Federation. In the same year, the Economic Security Strategy of the Russian Federation was approved. To date, this decree has lost its legal force, but the system of indicators is worthy to be studied independently.

This system included only economic indicators without affecting other areas that could directly or indirectly affect the economic situation in the country.

Another group of indicators determining the economic security of regions was proposed by the Center for Financial and Banking Research of the Institute of Economics of the Russian Academy of Sciences. This list includes 19 economic indicators (Kuznetsova, 2015).

The presented system of indicators includes only economic ones without affecting social, environmental, and political processes though they directly affect the economic security level. Moreover, all these indicators may not be applied at the regional level, since the regional budget does not provide for some indicators present in this system.

S.Yu. Glazyev and V.V. Lokosov (2012) developed a new and more meaningful system of indicators and divided it into five subsystems.

This system includes a number of other subsystems in addition to the economic ones, and it distinguishes it from the pre-existing economic security systems in the Russian Federation. It has already taken into account the effects of human potential and political interactions between society and the state.

But all the indicators systems developed in the Russian Federation do not include the environmental factor as it is done in the economic security indicators system developed by the UN Security Commission.

The recent system of economic security indicators in the Russian Federation was approved on May 13, 2017 by Decree of the President of the Russian Federation No. 208 entitled "Strategy for the economic security of the Russian Federation for the period until 2030". This system of indicators contains economic indicators exclusively (President of the Russian Federation, 2017).

The Federal State Statistics Service of the Russian Federation annually publishes economic and statistical data according to the list of indicators approved by Decree of the President of the Russian Federation No. 208 of May 13, 2017. This allows to quickly analyzing economic security using the data from the State Statistics Service.

After the global financial crisis of 2008 and transformations in the virtual sector of the economies in many countries, taking into account differences in the structure of borrowings (state debt, regional debts, corporate debts, interbank borrowings, household debt burden), the problem of an individual country economic security having a high level of public debt and the problem of the economic security of countries belonging to various communities and blocs, i.e. having associated economies became obvious.

This problem is most relevant for the countries of the Asia-Pacific region, since the competition for leadership in this region is quite high, and the economies of the countries in this region are of heterogeneous character when such countries as Singapore and Indonesia have an outstripping growth rate and countries like Laos or Timor-Leste demonstrate a stagnant economic trend (Im, 2018). 
Besides, the countries of the Asia-Pacific region are directly pressured by the integration processes of direct investment by states located outside their borders, but included in joint blocs such as ASEAN and APEC (Changzheng, 2013).

Figure 1 shows the flows of direct investment in the countries of Southeast Asia from 2010 to 2018 according to the World Bank.

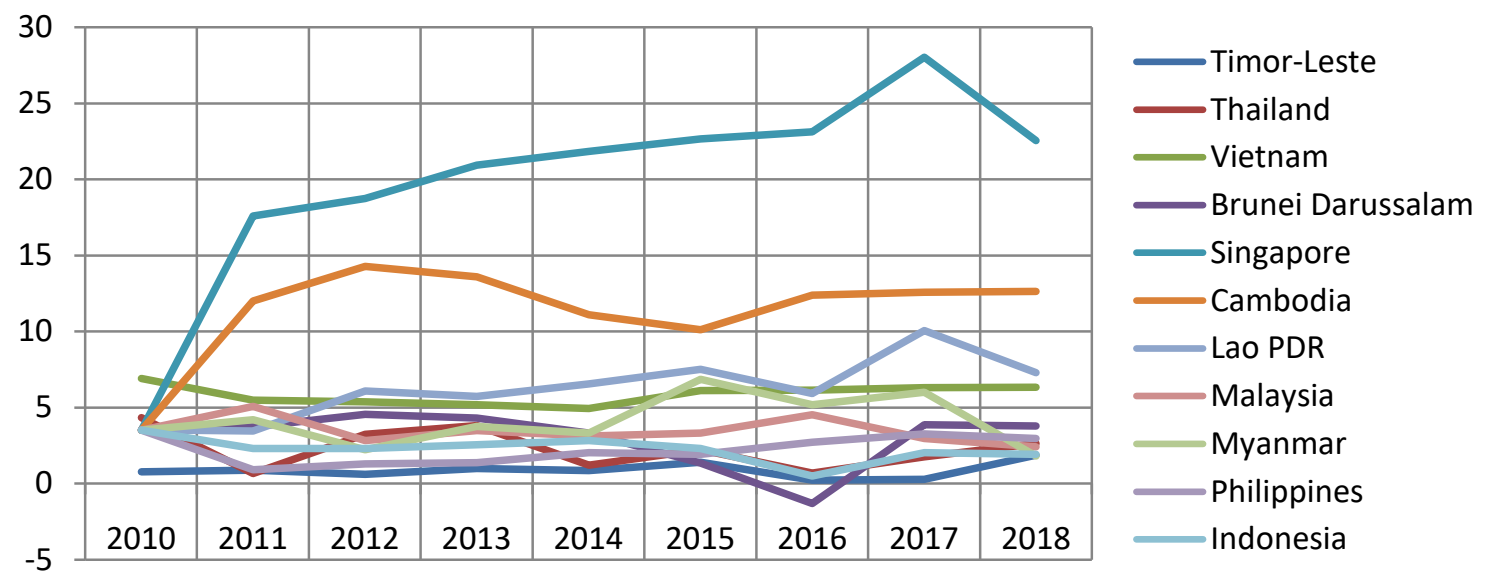

Figure 1 - FDI, ASEAN, 2010-2018

(Source: UN data)

The results obtained in Figure 1 make it possible to say with confidence that the region leaders in terms of investment attractiveness over the past 8 years are Singapore and Cambodia. To establish the country's dependence on investments, the ratio of direct investments to the volume of GDP in 2018 was established (Table 2).

Table 2 - FDI ratio to the volume of GDP in 2018

(Source: UN data)

\begin{tabular}{|l|c|c|c|}
\hline Countries & $\begin{array}{c}\text { Direct investments } \\
\text { (billion dollars) }\end{array}$ & GDP (billion dollars) & $\begin{array}{c}\text { Direct investment } \\
\text { to GDP in\% }\end{array}$ \\
\hline Timor-Leste & 1,856877 & 2,582 & 71,91 \\
\hline Thailand & 2,623494 & 504,992 & 0,51 \\
\hline Vietnam & 6,327862 & 244,948 & 2,58 \\
\hline Brunei Darussalam & 3,770129 & 13,567 & 27,78 \\
\hline Singapore & 22,52865 & 364,157 & 6,181 \\
\hline Cambodia & 12,62661 & 22,572 & 55,93 \\
\hline Lao PDR & 7,278307 & 18,17 & 40,05 \\
\hline Malaysia & 2,41855 & 354,348 & 0,68 \\
\hline Myanmar & 1,813101 & 71,214 & 2,54 \\
\hline Philippines & 2,962249 & 330,91 & 0,89 \\
\hline Indonesia & 1,919813 & 1042,973 & 0,18 \\
\hline
\end{tabular}

Cambodia, Laos and Timor-Leste are strongly influenced and dependent on direct investment. It is important to note that the economic security of these three countries will be formed under the influence of foreign investors thereby weakening self-sufficiency and 


\section{NATIONAL AND REGIONAL ECONOMIC SECURITY}

independence from foreign capital and determining the economy development direction.

To determine the economic pressure and destabilizing external factors influencing macroeconomics, it is important to establish an analytical apparatus i.e. an adapted or universal model determining the level of economic security, though all existing methods do not allow constructing an analysis covering this area.

Another aspect requiring independent consideration when determining the external influence on a country is its colonial dependence in the past because it has directly left its mark on socio-cultural values, corporate culture and political worldview as a whole.

The problem of economic security should be given a particular importance in the time of economic warfare including the ones between economic leaders; it is enough to recall the US sanctions against the Chinese Huawei Technologies Co. Ltd. and other firms having partnerships with many companies all over the world. An example of such sanction pressure is the construction of Nord Stream 2 gas pipeline by PJSC Gazprom.

Large German and Swiss companies assisting in this process implementation may face the risk of being included in the sanctions list. It can undermine the economic situation of companies if they are on the sanctions list, and since they are mainly large transnational giants forming the lion's share of their countries' GDP, the damage from being enlisted will affect the economies of these states.

An example of another type of economic dependence and pressure is the Republic of Cuba. Firstly, Cuba is an island state divorced from the major world economies and it cannot develop in a positive progression without constant support. The situation of island states economies is complicated by the lack of a self-sufficient mineral reserves and it makes them directly dependent on the countries importing such resources. Secondly, Cuba has been under US sanctions for several decades and this fact limits its access to important markets and investments.

In the sanctions context, primarily from the United States, it is possible to come up with a new approach to an old problem of economic independence of relatively small and economically dependent countries (Vietnam in particular). To maintain a balance of economic interests, Vietnam is forced to dull the genetic memory associated with the victims of the American invasion, for example, they even renamed the "The House of War Crimes of American Imperialism and the Puppet Government of South Vietnam" into the "War Remnants Museum ". Economic interests can depreciate genetic memory of the hostilities effects for some time.

However, the flourishing of an individual country can lead to a resuscitated memory of military victims. At present, the first economy of the world i.e. China can make it possible to revalue and realize the loss of the Chinese in the Second World War. According to $\mathrm{Xi}$ Jinping only about 35 million people died in the Second Sino-Japanese war.

All these political issues are quite difficult and sometimes it is impossible to reflect them in the economic security analysis of a country, especially when we analyze the bloc the country is a member of.

In all associations and commonwealths (except the $\mathrm{UN}$ ) there are no departments or services responsible for economic security ensuring its regulation, and these countries are put at risk of economic instability.

It is quite difficult to calculate the level of economic security in such commonwealths, since the development level of commonwealth member countries vary rather widely (Kiyoshi, 2014). 
The problem with all the methods determining the economic security level consists in getting results reflecting the interests of the body developed this methodology.

In the course of study of economic security methods and materials, it was noticed that none of the described methods and scientific papers consider economic security from the view point of labor migration. Labor migration is rather relevant for a number of regions facing this situation. The calculation complexity lies in the fact that labor migration has a twofold property, firstly, if a region suffers the population loss, it also loses highly qualified personnel, and it undermines labor productivity of a region, secondly, (this situation is relevant for backward countries with labor migration to more developed countries) the region having population shrinkage is exempted from the budgetary burden for these citizens social assistance, moreover, it receives financial flows into the country through remittances sent by migrant workers to their families. It is quite difficult to calculate such an indicator due to the lack of reliable information concerning the number of labor migrants (illegal) and the amount of funds taken out.

\section{Hypotheses}

The following hypotheses were put forward in the framework of this study:

Hypothesis 1: narrow production specialization, high level of economic openness, the lion's share of imports for essential goods, including food, as well as significant presence of multinational companies, large financial banks and financial institutions in the national market, the presence of industrial production over-integrated through foreign countries partnerships (suppliers) lead to external economic dependence undermining the economic security of the country.

Hypothesis 2. To provide sustainable development of the economy and to increase the economic growth rates of island states, it is necessary for them to be adapted and integrated into the larger and stronger economies of neighboring states. Such integration will weaken or completely deprive of economic security, but will provide an opportunity for economic development and comfortable living for people of this territory.

Hypothesis 3: The movement vectors in terms of economic security of individual countries being simultaneously included in several economic blocks (for example, China is a dialogue partner in BRICS, SCO, ASEAN) create economic sustainability in connection with mutual interests and goals.

Hypothesis 4: High degree of industrial production localization of one or several brands in a country may attract investors due to the market monopolization in a certain industrial segment (The Thai automotive market is dominated by Japanese automakers, and this fact prevents Chinese or South Korean automobile concerns to enter this market; it is shown in Figure 2). 


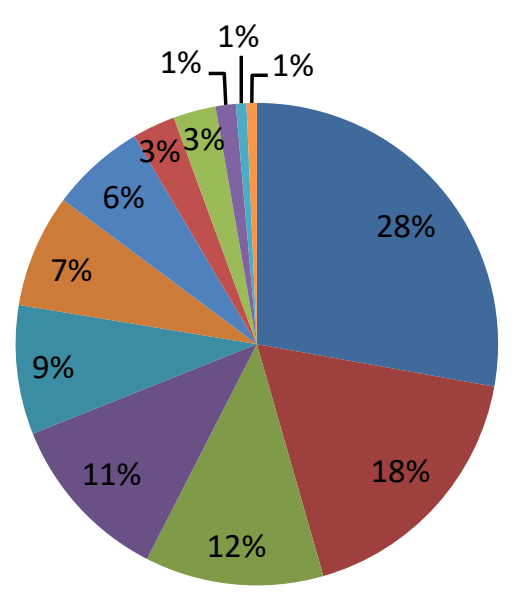

Toyota
Mitsubishi
Isuzu
Honda
Ford
Nissan
Mazda
Chevrolet
Suzuki
MG
Mercedes-Benz
BMW

Figure 2 - Car production in Thailand, 2018

(Source: https://auto.vercity.ru/statistics/production/asia/2018/thailand/)

The data in Figure 2 shows that $85 \%$ of the car manufacturing market is occupied by the Japanese automobile industry brands: Toyota - 28\%, Mitsubishi - 18\%, Isuzu - 12\%, Honda - 11\%, Nisan - 7\%, Mazda - 6\% and Suzuki - $3 \%$ The remaining niche of $15 \%$ is shared between the brands of Germany and the USA.

It is necessary to create a mechanism preventing any attempts to monopolize the market (natural monopolies are an exception) in order to avoid dependence on foreign influence on the economy and political processes in the country.

\section{Results}

Basing on the indicators data of all the above mentioned methods, we have compiled a table of indicators being included in most of the studied methods; the list of the indicators is presented in Table 2 .

The presented Table 2 demonstrates that one indicator is highlighted in all methods (Government debt, \% of GDP) and 10 indicators are highly used in most methods. These indicators are the main ones to be chosen when developing the authorial regression model of the national economic security.

Studying the heterogeneity of economic security in the Asia-Pacific region, we came to the conclusion that it is necessary to include indicators of geopolitical stability (political, economic or military pressure influencing a country) when measuring the level of economic security. Nowadays it is still difficult to develop such an indicator due to the country heterogeneity and criteria selection relevance when calculating this indicator. 
Table 2 - The list of indicators found in all studied methods

\begin{tabular}{|c|c|c|c|c|c|}
\hline Indicators & 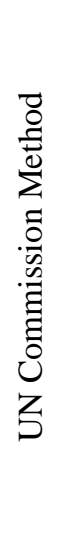 & 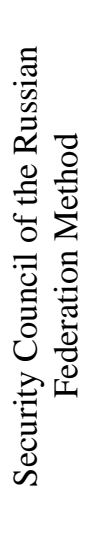 & 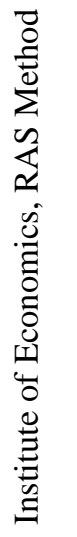 & 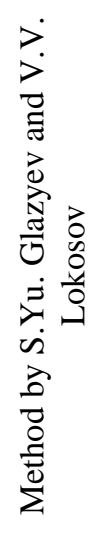 & 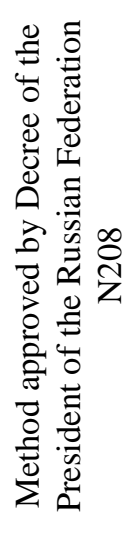 \\
\hline GDP per capita & + & + & + & & + \\
\hline Research and development costs, \% of GDP & + & + & + & + & \\
\hline Government debt ,\% of GDP & + & + & + & + & + \\
\hline Unemployment rate, \% & + & + & + & + & \\
\hline Average life expectancy & + & + & & + & \\
\hline Inflation rate per year, $\%$ & & + & & & + \\
\hline Monetization level, $\%$ of GDP & & + & + & + & \\
\hline Budget deficit & & + & + & + & + \\
\hline Volume of investments in fixed assets & & & + & + & + \\
\hline Volume of domestic debt,\% of GDP & & + & + & + & + \\
\hline Volume of investments in fixed assets, $\%$ of GDP & & & + & + & \\
\hline
\end{tabular}

\section{Conclusions}

It is advisable to include not only purely economic indicators into the proposed model of the country's economic security, but it is also reasonable to determine the significance of individual parameters by expert knowledge to obtain an adequate integrated value.

It is noteworthy that when we select indicators for the Russian Federation it is of a particular importance to consider the political situation of the Russian Federation, the area of the state and the conditions of possible sanction pressure from competing countries. Sanctions primarily imposed by the world economic giants or the mutual exchange of restrictions can have a strong indirect impact on the business climate of small economies connected with one of the economic conflict parties.

It is important to test an adaptive method for the Russian Federation using a retrospective analysis dynamics.

In the course of this study we have attempted to develop a system of indicators based on the country size, economy and population structure, economy development level to assess a group of countries.

State support for research and training in the field of security will make it possible to absorb potential economic threats. Thus, in Russia there are about 135 universities where students are trained in 38.05.01 "Economic Security" specialty with specialization in 05.10.04 "Information and Analytical Security Systems", 05.10 .05 "Security of Information Technologies in Law Enforcement Spheres". This fact proves the importance of this educational program for the state and business. 


\section{NATIONAL AND REGIONAL ECONOMIC SECURITY}

\section{References:}

Changzheng, D. J (2013). Global Policy. Retrieved https://link.springer.com/article/10.1007\%2Fs40320-013-0031-6.

Denis, H. (2014). Seguridad Economica el sistema de diagnostic. Retrieved from: http://www.idinteligencia.com/2014/10/03/diagnostico-de-seguridad-economica/

Glazyev, S.Yu. \& Lokosov, V.V. (2012) Assessment of the extreme critical values of indicators of the state of Russian society and their use in the management of socio-economic. Bulletin of the Russian Academy of Sciences.

Haikel, G. (2004). La Seguridad Economica. Ministerio de Educacion Superior. Retrived from: https://www.monografias.com/trabajos15/seguridad-economica/seguridadeconomica.shtml

Im, H. B. (2018) East Asian Community Rev. Retrieved from: https://link.springer.com/article/10.1057\%2Fs42215-018-0001-9.

Kazakova, N.A., Bolvachev, A.I. \& Gendon, A.L. (2016). Stud. Russ. Econ. Dev. 27: 638. Retrieved from: https://link.springer.com/article/10.1134/S107570 0716060058.

Kuznetsova, E.I. (2015) Competitive relations development and state economic strategy . Retrieved from: https://studref.com/555712/ekonomika/razvitie_konkurentnyhotnosheniy_ i_ekonomicheskaya

Manokhina, N.V. (2018). Economic security. Retrieved From: https://studref.com/660296/ekonomika/ekonomicheskaya_bezopasnost

Kiyoshi, M. (2014). China repeats manipulation of public figures for national sentiment. Retrieved from: https://jbpress.ismedia.jp/articles/-/40575

President of the Russian Federation (2017). On the Economic Security Strategy of the Russian Federation for the period until 2030: Decree of the President of the Russian Federation on 05/13/2017, 208.

Paper submitted

Paper accepted for publishing

Paper published online
16 December 2019

22 February 2020

02 April 2020 